\title{
Decarboxylative Conversion of Hydroxycinnamic Acids to Hydroxystyrenes by Polyporus circinata
}

\author{
By H. G. BAYNE, B. J. FINKLE AND R. E. LUNDIN \\ Western Regional Research Center, Agricultural Research Service, \\ U.S. Department of Agriculture, Berkeley, California 94710, U.S.A.
}

(Received 25 November 1975 ; revised 9 March 1976)

\section{INTRODUCTION}

Higher plants synthesize a large number of aromatic acids that often occur as aromatic alcohol derivatives (phenolic acids) or as esters. Many of these compounds are resistant to biodegradation. They are, however, metabolized by various micro-organisms, including members of the family Polyporaceae which can decompose the lignin of woody plants.

We examined the ability of the white rot fungus Polyporus circinata to utilize 3,4dihydroxycinnamate as a sole carbon source. In the course of our investigations, it became apparent that an early degradative step was a non-oxidative decarboxylation to hydroxystyrene. The bacterium Aerobacter aerogenes is known to degrade hydroxycinnamic acids in a similar manner, but such a reaction has not been reported previously for mycelial fungi or higher organisms.

\section{METHODS}

Polyporus circinata NRRL2903 was obtained from the Northern Regional Research Center, Peoria, Illinois, U.S.A. The culture was grown and maintained on Sabouraud Maltose Broth containing $2 \%(\mathrm{w} / \mathrm{v})$ yeast extract. For large scale cell production, several $48 \mathrm{~h}$ cultures grown at $28^{\circ} \mathrm{C}$ on a rotary shaker were inoculated into six Fernbach flasks each containing $350 \mathrm{ml}$ broth. They were incubated for an additional $48 \mathrm{~h}$ on a reciprocal shaker (100 strokes $/ \mathrm{min}$ ) washed with 61 sterile water, and then introduced into two flasks, each containing $500 \mathrm{ml}$ salts-substrate medium. This medium contained (per 1): $\mathrm{NaCl}$, I g; $\mathrm{NH}_{4} \mathrm{Cl}$, I g; $\mathrm{MgSO}_{4} .7 \mathrm{H}_{2} \mathrm{O}, 0.05 \mathrm{~g} ; \mathrm{MnSO}_{4}$, 0.00I g; $\mathrm{FeCl}_{3} .6 \mathrm{H}_{2} \mathrm{O}$, 0.0I g; $\mathrm{CaCl}_{2}, 0.005 \mathrm{~g}$; $\mathrm{I} \cdot \mathrm{O} \mathrm{M}$-cis, cis, cis, cis-I,2,3,4-cyclopentane tetracarboxylic acid (CIS) buffer $\mathrm{pH} 5 \cdot 0,200 \mathrm{ml}$; $0.2 \%(\mathrm{w} / \mathrm{v})$ 3,4-dihydroxycinnamic acid in $0.05 \mathrm{M}$-potassium phosphate $\mathrm{pH} 6.3,200 \mathrm{ml}$. The cells were incubated for 0.75 to $\mathrm{I} \cdot 5 \mathrm{~h}$, washed, weighed and frozen until used. The yield was usually about $300 \mathrm{~g}$ wet weight of cells from six flasks. Thawed cells were used in all experiments reported here.

For the decarboxylation reaction, a suspension of $\mathrm{I} 60 \mathrm{~g}$ cells in $0.02 \mathrm{M}-\mathrm{CIS}$ buffer $\mathrm{pH} 5.2$ $(\mathrm{I} 60 \mathrm{ml})$ was inoculated into $0.2 \%(\mathrm{w} / \mathrm{v})$ 4-hydroxycinnamic acid or 3,4-dihydroxycinnamic acid $(480 \mathrm{ml}), \mathrm{I} \cdot 0 \mathrm{M}$-CIS buffer $\mathrm{pH} 5.0$ ( $160 \mathrm{ml})$ and salts medium ( $160 \mathrm{ml})$, then incubated at $28{ }^{\circ} \mathrm{C}$ on a reciprocal shaker. At intervals samples were removed, filtered and the filtrates diluted $\mathrm{I}: 100$ in $0.05 \mathrm{M}$-potassium phosphate buffer $\mathrm{pH} \mathrm{6.3}$ for spectrophotometric analysis. The mixture remaining after completion of a reaction was filtered through Whatman no. 5 paper and frozen; and the acidified filtrate was extracted with ether, concentrated, and stored at $-30^{\circ} \mathrm{C}$.

Cell-free extracts were prepared from a $25 \%(\mathrm{w} / \mathrm{v})$ cell suspension in $0.02 \mathrm{M}$-CIS buffer pH 5.2 employing a Manton-Gaulin APV Industrial Homogenizer. Centrifugation was at 
$27000 \mathrm{~g}$ for $40 \mathrm{~min}$. The crude supernatant obtained was fractionated by precipitation in $20,40,60$ or $80 \%$ saturated ammonium sulphate solution. Ammonium sulphate fractionation was followed by dialysis for $\mathrm{I} 8 \mathrm{~h}$ in $0.02 \mathrm{M}$-CIS buffer $\mathrm{pH} 5 \cdot 2$.

\section{RESULTS}

Incubation of whole cells of $P$. circinata with 4-hydroxycinnamic acid for 5 h produced a compound having an absorption peak at $257 \mathrm{~nm}$. Paper chromatography demonstrated the presence of a reaction product showing a dark blue fluorescence. Its $R_{F}$ values relative to 4-hydroxycinnamic acid in four solvents, and also its extinction coefficient at $258 \mathrm{~nm}$, conformed to those previously reported for 4-hydroxystyrene (Finkle et al., 1962). The product was extracted and recrystallized according to the procedures of Dale \& Hennis (1958), and showed the characteristic reactions of 4-hydroxystyrene: m.p., 70 to $7 \mathrm{I}{ }^{\circ} \mathrm{C}$; grey-green colour with $\mathrm{I} \% \mathrm{FeCl}_{3} \cdot 6 \mathrm{H}_{2} \mathrm{O}$; cornflower blue colour with concentrated $\mathrm{HCl}$; yellow-orange colour with concentrated $\mathrm{H}_{2} \mathrm{SO}_{4}$, later turning red. Identification of the crystalline product was confirmed by nuclear magnetic resonance spectrometry. It had a proton magnetic resonance spectrum (I00 MHz, dry $\left[{ }^{2} \mathrm{H}_{6}\right]$ acetone) as follows: $\delta=8.34$ (s, I $\mathrm{H}$, aromatic $\mathrm{OH}) ; 6.66\left(\mathrm{dd}, \mathrm{I} \mathrm{H}, J=17, \mathrm{I0} \mathrm{Hz}, \stackrel{{ }^{*} \mathrm{H}}{C_{\mathrm{H}}}\right) ; 5.03\left(\mathrm{dd}, \mathrm{I} \mathrm{H}, J=\mathrm{I0}, \mathrm{I} \mathrm{Hz}, \stackrel{{ }^{\mathrm{H}}}{=} \nearrow_{\mathrm{H}}^{\mathrm{H}^{*}}\right)$; $5.5^{8}\left(\mathrm{dd}, \mathrm{I} \mathrm{H}, J=\mathrm{I} 7, \mathrm{I} \mathrm{Hz}, \stackrel{\mathrm{H}_{\searrow}}{\mathrm{H}^{*}}\right) ; 7 \cdot 30\left(\frac{1}{2} \mathrm{AA}^{\prime} \mathrm{BB}^{\prime}, 2 \mathrm{H}\right.$, meta to $\left.\mathrm{OH}\right) ; 6 \cdot 8 \mathrm{I}\left(\frac{1}{2} \mathrm{AA}^{\prime} \mathrm{BB}^{\prime}\right.$, $2 \mathrm{H}$, ortho to $\mathrm{OH}$ ). Except for a shift in the position of the hydroxyl resonance that is often observed, all shielding values agree with those for 4-hydroxystyrene reported by Finkle et al. (1962).

The incubation of whole cells with 3,4-dihydroxycinnamic acid for $5.5 \mathrm{~h}$ yielded a product having an absorption peak and extinction coefficient at $258 \mathrm{~nm}$ characteristic of 3,4-dihydroxystyrene (Finkle et al., 1962). Precipitates from cell-free extracts $80 \%$ saturated with ammonium sulphate were also able to degrade 3,4-dihydroxycinnamic acid, yielding a product with an absorption peak at about $258 \mathrm{~nm}$. If the ammonium sulphate fraction was boiled for $10 \mathrm{~min}$, degradation of 3,4-dihydroxycinnamic acid or 4-hydroxycinnamic acid no longer occurred. Protocatechuic and cinnamic acids, catechol, dihydroxyphenylalanine and dihydroxyphenylethylamine were inactive as substrates. Refractionation with ammonium sulphate demonstrated 3,4-dihydroxycinnamic decarboxylase activity in the 40 to $60 \%$ saturated ammonium sulphate fraction ( $\mathrm{pH}$ optimum, 6.1). At higher ammonium sulphate concentrations ( 70 to $80 \%$ saturated), the fractions were devoid of decarboxylase activity but readily attacked chlorogenic acid, the quinic ester of 3,4dihydroxycinnamic acid, to give a spectrum with peaks near $287 \mathrm{~nm}$ and $312 \mathrm{~nm}$. These are characteristic of 3,4-dihydroxycinnamic acid, presumably formed by hydrolysis (Lewis \& Thompson, I96I).

\section{DISCUSSION}

This paper aescribes the biological decarboxylaion of hydroxycinnamic acids to hydroxystyrenes by a mould, or extracts of a mould. When placed in contact with the substrate, whole cells of $P$. circinata that had been grown in the absence of substrate, rapidly degraded 3,4-dihydroxycinnamic acid, strongly suggesting that the decarboxylase is constitutive. The reaction promoted by whole cells and cell-free extracts resembled that of the bacterium 
Aerobacter aerogenes in decarboxylating hydroxycinnamic acids. Similar conversion reactions have been observed for other bacteria (Finkle et al., 1962; Indahl \& Scheline, 1968), for yeasts (Chen \& Peppler, I956; Manitto, Gramatica \& Ranzi, 1975), and in the cooking and alcoholic fermentation of grain (Steinke \& Paulson, 1964).

Fungal decarboxylation of trans-cinnamic acid to styrene was recorded for Aspergillus niger by Herzog \& Ripke (1908) and for Penicillium sp. by Jaminet (I950). Decarboxylation of hydroxycinnamic acids by fungi other than yeasts has not previously been reported. This decarboxylation and complementary reactions such as oxidations, polymerizations and demethylations are assumed to take place in the formation of soil humic acids (Finkle, I965) through the activity of associations of micro-organisms that decompose the lignin of woody material.

The authors acknowledge with appreciation the assistance of Mr Noel Hurd, University of California, Berkeley, for cooperative use of the Manton-Gaulin Homogenizer.

\section{REFERENCES}

Chen, S. L. \& Peppler, H. J. (1956). Conversion of cinnamaldehyde to styrene by a yeast mutant. Journal of Biological Chemistry 221, $101-106$.

Dale, W. J. \& Hennis, H. E. (1958). Substituted styrenes. III. The synthesis and some chemical properties of vinylphenols. Journal of the American Chemical Society 8o, 3645-3649.

FinkLe, B. J. (1965). Soil humic acid as a hydroxypolystyrene: a biochemical hypothesis. Nature, London 207, 604-605.

Finkle, B. J., Lewis, J. C., Corse, J. W. \& Lundin, R. E. (1962). Enzyme reactions with phenolic compounds: formation of hydroxystyrenes through the decarboxylation of 4 -hydroxycinnamic acids by Aerobacter. Journal of Biological Chemistry 237, 2926-293I.

Herzog, R. O. \& RIPKe, O. (I908). Conversion of cinnamic acid into styrene by molds. Zeitschrift für physiologische Chemie 57, 43-45.

INDAHL, S. R. \& Scheline, R. R. (1968). Decarboxylation of 4-hydroxycinnamic acids by Bacillus strains isolated from rat intestine. Applied Microbiology $\mathbf{1 6}, 667$.

JAMINET, F. (1950). Hydrocarbonic fermentation in a total syrup mixture. Journal of Pharmacology, Belgium 5, I9I-20I.

Lewis, J. C. \& Thompson, P. A. (1961). Microbiological production of chlorogenicase. Applied Microbiology 9, $205-208$.

Manitto, P., Gramatica, P. \& Ranzi, B. M. (1975). Stereochemistry of the decarboxylation of phenolic cinnamic acids by Saccharomyces cerevisiae. Journal of the Chemical Society, Chemical Communications $442-443$.

Steinke, R. D. \& Paulson, M. C. (I964). The production of steam-volatile phenols during the cooking and alcoholic fermentation of grain. Journal of Agriculture and Food Chemistry 12, 381-387. 